\title{
Who Is Targeted by the Council's Sanctions? The UN Security Council and the Principle of Proportionality
}

\author{
Daniëlla Dam-de Jong \\ Associate Professor, Grotius Centre for International Legal Studies, \\ Leiden University, Leiden, The Netherlands \\ d.a.dam@law.leidenuniv.nl
}

\begin{abstract}
The current article aims to assess proportionality within the context of the Security Council's practice, focusing specifically on how the Council balances various interests in the design of sanctions regimes adopted pursuant to Article 41 of the UN Charter. It argues that proportionality in this context plays a role in the Security Council's targeting decisions on the one hand and in the determination of whose interests are affected by the sanctions on the other. This implies that the Security Council should distinguish, first, between those who should be subjected to sanctions (the targets) and those would should be shielded (third parties) and, second, that it carefully delineates the targets of the sanctions. This article assesses this balancing exercise within the context of the Council's measures to curb the illegal exploitation of natural resources financing armed conflict on the one hand and with respect to countering the proliferation of nuclear weapons on the other.
\end{abstract}

\section{Keywords}

UN Security Council - sanctions - natural resources - non-proliferation

\section{Introduction}

The Security Council has been vested with the exclusive power to adopt coercive measures on behalf of the United Nations (UN) member States to address 
situations that amount to a threat to the peace or worse. ${ }^{1}$ As this mandate requires flexibility for the Council to choose the measures that best suit the situation, some authors argue that it seems difficult to reconcile with the principle of proportionality, ${ }^{2}$ understood in this context as requiring a proper balance between the injury caused by the coercive measures adopted by the Security Council and the gravity of the situation that is to be addressed. However, choosing the measures that best suit the situation is not at odds with the requirements of the principle of proportionality. The question seems to be instead how one determines whether there is a proper balance between the injury caused by the measures taken and the gravity of the situation that these aim to address. Arguably, this requires a clear understanding of the pool of interests affected by the measures. More precisely, it raises the question as to how the Security Council balances the various interests affected by its decisions and weighs these against the objectives it aims to pursue.

The current article assesses this balancing of interests within the context of the design of sanctions regimes adopted pursuant to Article 41 of the UN Charter. Proportionality in this context can be defined as the need to ensure that "the coercive consequences of the application of sanctions, which may be felt by civilian populations, third states or individuals, remain in proportion to the harm caused by the target against which sanctions are imposed and are consistent with the objectives for which sanctions were employed." ${ }^{3}$ This definition contains three elements. The first is that coercive measures are only imposed against those individuals and entities that are considered to be responsible for activities that contribute to the initiation or perpetuation of a threat to the peace. The second element sees to even-handedness, in the sense that there is a clear nexus between the measures imposed and the objectives of the sanctions. The third element requires that the injurious consequences for third actors ensuing from the application of sanctions are kept to a minimum.

It follows from this definition that proportionality plays a role in the Security Council's targeting decisions on the one hand and in the determination of whose interests are affected by the sanctions on the other. In other words, in designing sanctions the Security Council should first carefully distinguish between those who should be subjected to sanctions (the targets) and those would should be shielded (third parties). More specifically, it raises the question as to which

1 Articles 39 jo. 24 and 25 UN Charter.

2 See E. de Wet, The Chapter VII Powers of the United Nations Security Council (Hart Publishing, Oxford, 2004), p. 185.

3 J. Farrall, United Nations Sanctions and the Rule of Law (Cambridge University Press, Cambridge, 2007), p. 42. 
individuals or entities are subjected to sanctions and how this group is delineated. Second, an assessment of how the injurious effects of sanctions on third parties are kept to a minimum follows the targeting decision. This assessment requires an evaluation of whose interests are weighed and to what extent these are taken into account in decisions regarding the types and scope of sanctions.

For the purpose of answering these questions, section 2 sets out the international legal framework that guides the UN Security Council's sanctions practice and explores how this framework has been interpreted by the Council in its sanctions policy. Section 3 assesses how proportionality takes shape within the context of actual sanctions regimes. This section discusses the response of the Security Council in relation to the threats caused by the illegal exploitation of natural resources as a means to finance armed conflicts on the one hand and proliferation of nuclear weapons on the other. The reason for choosing these case studies is that they demonstrate the complexities of applying proportionality within sanctions practice. Section 4 offers some final thoughts on the principle of proportionality in this context, based on the analysis of the case studies.

\section{Proportionality in the Normative and Policy Framework Regulating UN Sanctions}

Chapter VII of the UN Charter provides the principal legal framework for assessing UN sanctions practice, as it sets out the enforcement mandate of the UN Security Council. It has built in minimum safeguards that aim to ensure that measures taken by the UN Security Council respect the principles of legality, necessity and proportionality. ${ }^{4}$ These implicit safeguards are the subject of

4 Although Chapter viI does not refer to these principles, its provisions contain implicit safeguards that give effect to the principles of legality, necessity and proportionality. Safeguards giving effect to the principle of proportionality are the subject of the current section. Examples of safeguards giving effect to the principles of legality and necessity include the requirement that measures must be based on a determined threat to the peace, breach of the peace or act of aggression and that they can only be adopted for the purpose of maintaining or restoring international peace and security. See K. Manusama, The United Nations Security Council in the Post-Cold War Era: Applying the Principle of Legality (Martinus Nijhoff, Leiden, 2006). Additional safeguards can be found in other parts of the UN Charter, most notably that Security Council decisions must respect the purposes and principles of the UN pursuant to Article 24(2) of the UN Charter. Whether this is an actual limitation to the powers of the Council, is subject to debate. See e.g. N. Krisch, 'Introduction to Chapter vir: The General Framework', in B. Simma et al. (eds.), The Charter of the United Nations: A Commentary (Oxford University Press, Oxford, third edition, volume II, 2012), pp. 2137-1271; and de Wet, supra note 2, pp. 191-195. 
the current section. At the same time, it should be noted that Chapter viI provides the Security Council broad discretion on how to interpret and carry out its mandate. Key terms have been left undefined to ensure this flexibility. ${ }^{5}$ As a consequence, the Security Council has considerable freedom to shape its sanctions practice. This does not imply that the Security Council has unfettered discretion, ${ }^{6}$ nor that it would be immune to criticism. It is precisely because of criticism and legitimacy concerns that the Security Council has developed additional safeguards through its practice. The current section discusses how proportionality has taken shape in the UN Charter and in the Council's policies with respect to sanctions design.

Article 39 of the UN Charter provides a useful starting-point for this inquiry, as it defines the purposes and legal basis for Security Council measures. This provision includes two safeguards that are relevant for sanctions design. First, Article 39 determines that the purpose of measures taken by the Security Council is to "maintain or restore international peace and security." Second, a combined reading of Article 39 on the one hand and Articles 41 and 42 on the other leads to the conclusion that the Security Council may adopt measures pursuant to the latter provisions only once it has determined the existence of a threat to the peace, a breach of the peace or an act of aggression. ${ }^{7}$ In other words, the measures adopted by the Security Council should both respond to a threat to the peace, breach of the peace or act of aggression and should contribute to addressing such situations. This presupposes that the Council should assess the relationship between means and end, tailoring the measures to address the situation in the most effective way.

Article 39 is however broadly formulated and does not provide any guidance on the proportionality of measures taken by the Security Council "to maintain or restore international peace and security." Article 41, which provides the legal basis for the imposition of sanctions, likewise fails to provide guidance. It provides full discretion to the Council to decide "what measures not involving the use of armed force are to be employed to give effect to its decisions." Potential

5 See generally Krisch, ibid., notably pp. 1237, and 1275-1276.

6 Article 24(2) of the UN Charter, which prescribes that "[i]n discharging [its] duties the Security Council shall act in accordance with the Purposes and Principles of the United Nations," has been interpreted as requiring respect by the Council of international humanitarian law, including its principles of necessity and proportionality. This interpretation has however also been contested by authors who take the view that the UN Security Council is not bound by international law. See for this discussion, M.E. O'Connell, 'Debating the Law of Sanctions,' 13:1 European Journal of International Law (2002) pp. 63-79.

7 In practice, the Security Council has almost exclusively relied on the notion of threat to the peace as a foundation for the adoption of measures. See e.g. Farrall, supra note 3, p. 64. 
measures include "complete or partial interruption of economic relations and of rail, sea, air, postal, telegraphic, radio, and other means of communication, and the severance of diplomatic relations," but this list is non-exhaustive.

The only hint to proportionality that is included in Chapter viI comes from Article 42. This provision determines that the Security Council may take forcible measures "[s]hould [it] consider that measures provided for in Article 41 would be inadequate or have proved to be inadequate." Krisch argues that this confirms that the principle of proportionality "forms part of the positive law of the Charter." ${ }^{8}$ For sanctions design, this limitation is mostly relevant as a confirmation that the impact of enforcement measures should be minimised as much as possible. Yet, it provides little guidance on how this should be accomplished.

It is therefore mainly through its practice that the Council has developed several tools to give effect to the principle of proportionality in the design of its sanctions. These tools were developed in response to criticism about the devastating impact of comprehensive economic embargoes on civilian populations. ${ }^{9}$ In a 1995 non-paper, the permanent members of the Security Council resolved that "further collective actions in the Security Council within the context of any future sanctions regime should be directed to minimize unintended adverse side-effects of sanctions on the most vulnerable segments of targeted countries."10 Humanitarian exemptions were among the first innovations in sanctions practice to mitigate the effects of sanctions on innocent third parties, most notably the civilian population. As a matter of policy, the Council determined in 1999 that objects such as foodstuffs, pharmaceuticals, medical supplies as well as basic or standard medical and agricultural equipment and basic or standard educational items should in any case be exempted from sanctions regimes. ${ }^{11}$ The Council furthermore emphasised that sanctions committees should monitor the humanitarian impact of the sanctions

8 Krisch, supra note 4, p. 126o.

9 This criticism was at its height in the 199os in relation to the sanctions regime imposed against Iraq to curtail its production in weapons of mass destruction. The tragedy that unfolded in Iraq set in motion an ambitious reform process of UN sanctions. See S.E. Eckert, 'The Evolution and Effectiveness of UN Targeted Sanctions,' in L.J. van den Herik (ed.), Research Handbook on UN Sanctions and International Law (Edward Elgar Publishing, Cheltenham, 2017), pp. 52-69.

10 Letter Dated 13 April 1995 from the Permanent Representatives of China, France, the Russian Federation, the United Kingdom of Great Britain and Northern Ireland and the United States of America to the United Nations addressed to the President of the Security Council, UN Doc. S/1995/300 (13 April 1995), p. 2.

$11 \quad$ Note by the President of the Security Council: Work of the Sanctions Committees, UN Doc. S/1999/92 (29 January 1999), para. 16. 
on vulnerable groups throughout the sanctions regime "and make required adjustments of the exemption mechanisms to facilitate the delivery of humanitarian assistance."12

However, the most important innovation developed by the UN Security Council to mitigate the effects of sanctions on third parties concerns the practice of 'smart sanctions.' Smart sanctions are valuable tools to achieve the three strategic purposes of sanctions: to coerce targets in changing their behaviour, to constrain actors in their ability to conduct certain activities and to stigmatise targets for violating international norms. ${ }^{13}$ All sanctions regimes that apply today are (to some extent) targeted..$^{14}$ Humanitarian exemptions are furthermore often included to further minimise harm on third parties.

Smart sanctions comprise 'selective sanctions,' defined as "less-than-comprehensive measures involving restrictions on particular products or financial flows," and 'targeted' sanctions, defined as "a subset of selective sanctions, specifically aiming for more narrow and precise effects, usually directed at a particular segment of the population in the targeted State."15 Selective sanctions usually consist of sectoral or commodity sanctions. They have been used by the Security Council throughout its sanctions practice. Already in 1966, the Council imposed commodity sanctions based on Article 41 of the UN Charter against the authorities in Southern Rhodesia for the purpose of putting an end to the illegal white minority regime ruling at the time. These sanctions included an import embargo on a range of commodities, including several minerals, sugar, tobacco, meat and other animal products as well as an export embargo on oil. ${ }^{16}$ In terms of effects, these sanctions would however not have differed from a comprehensive economic embargo, as they targeted the pillars of the Southern Rhodesian economy. ${ }^{17}$

12 Ibid., para. 11.

13 See S. Eckert, 'The Role of Sanctions,' in S. von Einsiedel, D.M. Malone and B. Stagno Ugarte (eds.), The UN Security Council in the 21st Century (Lynne Rienner Publishers, Boulder, 2016), p. 415.

14 Compendium of the High-level Review of United Nations Sanctions, UN Doc. A/69/941-S/2015/432 (12 June 2015), p. 69.

15 D. Cortright and G.A. Lopez (eds.), Smart Sanctions: Targeting Economic Statecraft (Rowman \& Littlefield, Lanham, 2002), p. 172. It should be noted that the distinction between selective sanctions and targeted sanctions is not always made. Sue Eckert, for instance, notes that "targeted measures include asset freezes, travel or visa restrictions, aviation bans, arms embargoes, and restrictions on commodities such as diamonds, timber, oil, charcoal, and luxury goods," thereby including selective sanctions within the category of targeted sanctions. See Eckert, 'The Role of Sanctions,' supra note 13, p. 415.

16 See UN Security Council Resolution 232 (1966), especially paras. 2(a) and (b).

17 In practice, the sanctions were not effective due to a lack of implementation by member States. For this reason, they were soon replaced by a comprehensive economic embargo 
Targeted sanctions predominantly take the form of travel restrictions or asset freezes imposed against designated individuals or entities. These may include governments and/or their officials, (members of) armed groups, political parties, terrorist organisations and corporations. Targeted sanctions are used widely by the Security Council and for a variety of purposes. Their use is probably best known in the context of the Council's efforts to counter terrorism, where their use has led to important procedural innovations, such as the introduction of an ombudsperson, to counter criticism with respect to due process concerns. ${ }^{18}$ However, they are also widely used within the context of conflict resolution (e.g. peace spoilers) and non-proliferation.

This "individualization of sanctions"19 constitutes the Council's primary method to ensure that measures are better tailored to inflict harm on the wrongdoer, while shielding innocent third parties, most importantly the civilian population. As noted by the Security Council itself in a Presidential Statement, "[ $\mathrm{t}]$ he Council resolves to ensure that sanctions are carefully targeted in support of clear objectives and are implemented in ways that balance effectiveness against possible adverse consequences. ${ }^{20}$ Referring back to the definition of proportionality as set out in section 1 , smart sanctions therefore aim to ensure that coercive measures inflict harm on those individuals and entities that are considered to be responsible for activities that contribute to the initiation or perpetuation of a threat to the peace (the targets) and that the injurious consequences for third actors ensuing from the application of sanctions are kept to a minimum. The following section tests this assumption through an inquiry into sanctions practice.

\section{Proportionality in Sanctions Practice}

This section delves into the Council's practice for the purpose of assessing whether and to what extent the Security Council adheres to the principle of

with exemptions applying to payments for pensions, medical, humanitarian and educational purposes.For more details regarding this sanctions regime, see P.J. Kuyper, The Implementation of International Sanctions: The Netherlands and Rhodesia (Sijthoff \& Noordhoff, Alphen aan den Rijn, 1978); and Farrall, supra note 3, pp. 247-253.

18 See K. Prost, 'Security Council Sanctions and Fair Process', in van den Herik (ed.), supra note 9, pp. 213-235.

19 L.J. van den Herik, 'The Individualization and Formalization of UN Sanctions,' in van den Herik (ed.), ibid., pp. 1-16.

20 Statement by the President of the Security Council, UN Doc. S/PRST/2006/28, 22 June 20o6, last paragraph. 
proportionality in the choice of its targets on the one hand and in the way in which it approaches the injurious consequences of sanctions for third parties on the other. It compares the Council's responses to two threats specifically. The first concerns the Council's response to the financing of armed conflicts through the illegal exploitation of natural resources. The principal targets of the measures imposed by the Security Council in this context are armed groups. The second concerns the Council's response to nuclear proliferation, which targets State authorities. Notwithstanding the differences in both targets and objectives of the relevant sanctions regimes, they have in common that the principal objective of the measures is to prevent the targets from obtaining the materials and revenues necessary to pursue their activities.

\subsection{Addressing Illegal Exploitation of Natural Resources}

The evolution of the Security Council's approach towards the trade in illegally exploited natural resources financing armed conflicts provides a good example of the Council's attempts to tailor its sanctions to more directly target the actors responsible for the existence of a threat to the peace. ${ }^{21}$ Measures targeting the illegal exploitation of natural resources have become a prominent feature of UN Security Council sanctions regimes ever since the 1991 Paris Peace Agreements concluding the armed conflict in Cambodia. In order to put pressure on the Khmer Rouge to comply with these agreements, the Security Council enforced a national moratorium on round logs established by the Cambodian Transitional Council. ${ }^{22}$ The measures were therefore selective: they targeted a specific natural resource because of its contribution to the financing of the activities of an armed group. At the same time, the measures were also relatively blunt, as they simply targeted all round logs originating from Cambodia. This demonstrates the limitations of applying selective sanctions. Notwithstanding the fact that they target specific goods or services, selective sanctions are not able to distinguish between goods that are used for prohibited and for legitimate purposes. These sanctions, when applied to natural resources that constitute important export products for a State, thereby risk to undermine the livelihood of the local population. ${ }^{23}$

21 This section builds on my earlier research, most notably D.A. Dam-de Jong, International Law and Governance of Natural Resources in Conflict and Post-conflict Settings (Cambridge University Press, Cambridge, 2015).

22 See UN Security Council Resolution 792 (1992), para. 13.

23 See also the 2016 Compendium, supra note 14, p. 69 which notes that: "Applying sanctions to trade in natural resources requires great care to avoid unintended consequences. With some exceptions, the targets for such sanctions are primarily non-state actors and armed opposition groups. Because the natural resources trade can serve as the main source of 
After this first experience targeting natural resources that contributed directly to conflict financing, the Security Council refined its approach in order to mitigate the effects of the sanctions on the development of the States to which the sanctions applied. For instance, the effects of the sanctions that were imposed for the purpose of curtailing the illegal exploitation of diamonds financing armed conflicts in several African States were mitigated by exemptions for diamond exports by the official authorities of these States. ${ }^{24}$ This was achieved by way of the introduction of a certificate-of-origin regime, established through the Kimberley Process for the Certification of Rough Diamonds. The Process brought together diamond producer and consumer States as well as the diamond industry and civil society, resulting in a system of export and import controls for the international trade in diamonds. ${ }^{25}$ The Kimberley Process enabled the States to which the diamond sanctions applied to continue exporting their diamonds, while curtailing the possibilities for armed groups to trade diamonds on the international market. In this way, the Security Council was able to directly target the armed groups who were considered responsible for undermining peace and security, while protecting the fragile economies of the States in which these armed groups operated.

The establishment of the Kimberley Process constituted an important innovation in sanctions practice which directly impacted on sanctions design. Once the Process had evolved into a fully functioning organisation with universal membership, the Council refrained from imposing diamond sanctions altogether. ${ }^{26}$ Instead, it started to include illegal exploitation of natural resources among the listing criteria for the imposition of financial and travel restrictions, thus shifting to targeted sanctions. This shift is part of a broader development, where the Council started to impose travel and financial restrictions on individuals and entities providing support for armed groups or criminal networks through the illicit exploitation of natural resources. Commensurate to this development, the Security Council increasingly focused its attention on the

revenue for the affected countries, there is an obvious possibility that legitimate trade could also be affected. Similarly, the non-state actors who seek to use natural resource revenues to fund conflict usually rely on artisanal communities and regional economic structures, often through coercion, to access and sell the resources. There is therefore a risk that sanctions targeting the sector could 'double victimise' these communities."

24 See e.g., UN Security Council Resolution 1295 (2000) on Angola, paras. 16 and 19; and UN Security Council Resolution 1446 (2002), para. 3 .

25 See https://www.kimberleyprocess.com/ for more information on the Kimberley Process.

26 See e.g. Press Statement on Sierra Leone Diamond Embargo by Security Council President, UN Doc. SC/7778, 5 June 2003, lifting the diamond sanctions on Sierra Leone; and UN Security Council Resolution 2127 (2013) on the Central African Republic, preamble and para. 56. 
supply chains of the natural resources that provided armed groups with the revenues to undermine the rule of law.

The sanctions regime regarding the Democratic Republic of the Congo (DRC) provides the most prominent example. In order to make an informed decision on which type of measures to impose to break the link between the exploitation of natural resources and the ongoing violence in the DRC, the Security Council requested two reports. The Group of Experts was requested to report on feasible and effective measures that the Council could impose, and the Secretary-General was asked to assess the economic, humanitarian and social impacts of such measures on the Congolese population. ${ }^{27}$ Whereas the Group of Experts recommended the imposition of selective commodity sanctions, the Secretary-General's report concluded that these sanctions would have negative impacts on artisanal miners and on the fragile peace process in the DRC. ${ }^{28}$ It was based on these humanitarian considerations that the Security Council decided to address the illegal exploitation of natural resources principally through the existing financial and travel sanctions. It extended these sanctions to "individuals or entities supporting the illegal armed groups [operating] in the eastern part of the Democratic Republic of the Congo through the illicit trade of natural resources." 29

This open-ended formulation paved the way for imposing sanctions on the supply chain as a whole for conducting irresponsible business practices. More specifically, the Security Council instructed the Group of Experts to draw up guidelines for the exercise of due diligence by the importers, processing industries and consumers of mineral products from the DRC. ${ }^{30}$ This resulted in a set of guidelines including a five-step risk-based approach to due diligence, mandatory for all corporations directly or indirectly sourcing minerals from the DRC. These five steps consisted of strengthening company management systems, identifying and assessing supply chain risks, designing and implementing strategies to respond to identified risks, conducting independent audits, and publicly disclosing supply chain due diligence and findings. A distinction was nevertheless made between corporations operating upstream (from mine to smelter/refinery) and downstream (from smelter/refinery to end product).

27 UN Security Council Resolution 1698 (2006), especially para. 6 and 8.

28 See Report of the Group of experts submitted pursuant to resolution 1654 (2006), UN Doc. S/2006/525, para. 159; Interim report of the Group of Experts submitted pursuant to resolution 1698 (2006), UN Doc. S/2007/40, para. 52; Report of the Secretary-General pursuant to paragraph 8 of resolution 1698 (2006) concerning the Democratic Republic of the Congo, UN Doc. S/2007/68 of 8 February 2007, para. 62-63.

29 UN Security Council Resolution 1857 (2008), especially para. 4(g).

30 UN Security Council Resolution 1896 (2009), especially para. 7. 
The burden of assembling the relevant information on the origin of minerals is placed with the upstream companies, while the principal obligation incumbent on downstream companies is to verify this information. ${ }^{31}$ The Security Council further decided that the failure to exercise due diligence consistent with the steps set out in the resolution could be a reason for an individual or entity to be placed on the sanctions list. ${ }^{32}$ This implies that all corporations using minerals or gold from the DRC in their products could in principle be sanctioned for "supporting the illegal armed groups [operating] in the eastern part of the Democratic Republic of the Congo through the illicit trade of natural resources" if they have not conducted proper due diligence. ${ }^{33}$

Although the sanctions regime with respect to the DRC is the most elaborate to date in imposing concrete obligations on the private sector, other sanctions regimes targeting illegal exploitation of natural resources financing armed conflicts also provide for the listing of individuals or entities providing support for armed groups or criminal networks through the illicit exploitation of natural resources. ${ }^{34}$ This is striking if considered from the perspective of proportionality. Looking at the evolution of the Security Council's approach with respect to illegal exploitation of natural resources financing armed conflicts, it is clear that the Security Council has attempted to tailor the sanctions to more directly target the actors responsible for undermining peace and security. At the same time, by adopting open-ended formulations for the listing criteria, the Security Council has widened the net of potential targets for sanctions, raising the question of whether these measures are proportional.

\subsection{Countering the Proliferation of Nuclear Weapons}

Whereas the previous section focused on proportionality with respect to targeting decisions, the current section explores proportionality from the perspective of balancing the interests of third parties. It does so within the context of the Council's non-proliferation efforts, as these regimes may have particular detrimental effects for the population of the State that is targeted. ${ }^{35}$ The sanctions regime against North Korea (DPRK) provides the most conspicuous contemporaneous example and is therefore used as the principal case study in this section.

$31 \quad$ Final report of the Group of Experts prepared pursuant to paragraph 6 of Security Council Resolution 1896 (2009), UN Doc. S/2010/596, para. 328-369.

$32 \quad$ UN Security Council Resolution 1952 (2010), especially para. 9.

33 UN Security Council Resolution 1857 (2008), especially para. 4(g).

34 See e.g., UN Security Council Resolution 2213 (2015), para. 11(c) on Libya.

35 Also see on this topic D. Joyner, 'UN Counter-Proliferation Sanctions and International Law, in van den Herik (ed.), supra note 9, pp. 105-124. 
The DPRK sanctions regime was established in 2006 to coerce the North Korean government to abandon its ballistic and nuclear programmes, most notably by constraining its access to critical resources and finances. ${ }^{36}$ Subsequent resolutions were adopted in 2009 and 2013 respectively, ${ }^{37}$ in response to nuclear tests conducted by the North Korean authorities. The measures imposed through these resolutions included an arms embargo, an embargo on materials that can be used for the production of weapons, a ban on luxury goods as well as financial and travel restrictions for senior officials and for persons directly involved in North Korea's weapons programmes. These measures, with the exception of the ban on luxury goods, were therefore directly connected to the threat posed by North Korea's weapons programmes.

However, the sanctions regime was rapidly intensified through a series of resolutions adopted in 2016 and 2017 in response to provocations by the DPRK, including the test launch of an engine for intercontinental ballistic missiles on 9 April 2016 and of its first actual intercontinental ballistic missile on 4 July $2017 .{ }^{38}$ The measures that have been imposed through these resolutions are wide-ranging. Some of these measures directly support the existing sanctions. Most notably, Resolution 2270 (2016) mandated all States to carry out inspections of cargo that can be connected to the DPRK "for the purposes of ensuring that no items are transferred in violation of resolutions 1718 (2006), 1874 (2009), 2087 (2013), 2094 (2013) and this resolution."39 It also mandated States to "prohibit their nationals and those in their territories from leasing or chartering their flagged vessels or aircraft or providing crew services to the DPRK" or persons related to the regime. ${ }^{40}$ In response to reports outlining

36 See UN Security Council Resolution 1718 (2006) and subsequent resolutions. A full overview of adopted resolutions in relation to the DPRK is available at https://www.un.org/ securitycouncil/sanctions/1718/resolutions, accessed 2 November 2019; see also UN Security Council Resolution 2397 (2017), preambular para. 5, in which the Council acknowledges "that the proceeds of the DPRK's trade in sectoral goods, including but not limited to coal, iron, iron ore, lead, lead ore, textiles, seafood, gold, silver, rare earth minerals, and other prohibited metals, as well as the revenue generated from DPRK workers overseas, among others, contribute to the DPRK's nuclear weapons and ballistic missile programs."

37 See UN Security Council Resolution 1874 (2009); 2087 (2013); and 2094 (2013).

38 See BBC News, "North Korea 'tests long-range missile engine," 9 April 2016, available at https://www.bbc.com/news/world-asia-36oo2713, accessed 1 November 2019; and BBC News, 'North Korea hails 'ICBM test' success', 4 July 2017, available at https://www.bbc.com/news/ world-asia-40491138, accessed 1 November 2019.

39 UN Security Council Resolution 2270 (2016), para. 18.

40 Ibid., para. 19. 
North Korea's sophisticated methods to evade these sanctions, subsequent resolutions strengthened the inspection requirements, yet to no avail. ${ }^{41}$

In addition to these measures which aim to prevent materials for the production of weapons from entering the DPRK, the sanctions regime also includes sanctions which aim to cut off finances for the regime. In addition to the asset freezes that were imposed through earlier resolutions, Resolutions 2371 (2017), 2375 (2017) and 2397 (2017) include several selective sanctions on goods and services which provide the State with revenues. These include sanctions on a variety of minerals, crude oil, petroleum, food and agricultural products, seafood, machinery, electrical equipment, textiles, wood as well as a prohibition to employ North Korean workers.

The relevant resolutions explicitly state that the measures that are imposed "are not intended to have adverse humanitarian consequences for the civilian population of the DPRK."42 In order to mitigate the effects of the sanctions on the population, the Security Council has introduced exemptions for some of the sanctioned goods. The sanctions on crude oil and refined petroleum, for instance, prohibit member States to directly or indirectly supply, sell or transfer these goods to the DPRK, but exempt a certain amount of barrels for livelihood purposes and provide for the possibility to request additional exemptions for such goods used exclusively for livelihood purposes. ${ }^{43}$ Furthermore, the Security Council decided in Resolution 2397 (2017) that the sanctions committee responsible for the implementation of the sanctions against the DPRK "may, on a case-by-case basis, exempt any activity from the measures imposed by these resolutions if the committee determines that such an exemption is necessary to facilitate the work of [humanitarian] organisations in the DPRK or for any other purpose consistent with the objectives of these resolutions." 44 In response to this resolution, the sanctions committee has developed guidelines to simplify the procedures for obtaining humanitarian exemptions. ${ }^{45}$ Notwithstanding these exemptions, the situation in North Korea is dire. This

41 The most recent report adopted by the UN Panel of Experts noted, for instance, that North Koreas "has continued to violate the resolutions through the conducting of illicit ship -to-ship transfers." See Report of the Panel of Experts established pursuant to resolution 1874 (2009), UN Doc. S/2019/691, 31 July 2019, para. 2.

42 See e.g. UN Security Council Resolution 2371 (2017), preambular para. 5.

43 See UN Security Council Resolution 2397 (2017), paras. 4 and 5.

44 Ibid., para. 25.

45 See Implementation Assistance Notice No. 7: Guidelines for Obtaining Exemptions to Deliver Humanitarian Assistance to the Democratic People's Republic of Korea, 6 August 2018, available at https://www.un.org/securitycouncil/sites/www.un.org.securitycouncil/ files/1718_implementation_assistance_notice_7.pdf, accessed 2 November 2019. 
is partly caused by the collapse of the banking channel and the difficulties of transferring funds more generally. ${ }^{46}$

The DPRK sanctions regime clearly shows the challenges that arise when targets are not responsive to the pressure exerted on them. This is especially so when it concerns an isolationist and oppressive State such as the DPRK, which prohibits its citizens to engage directly in transboundary commercial relations. Nevertheless, the DPRK sanctions regime also demonstrates the Council's intention to adhere to the principle of proportionality. This is evident both from the approach adopted by the Security Council, which was one of incrementally increasing pressure on the DPRK regime through successive resolutions, and from the Council's efforts to reduce the adverse effects of the sanctions on the population. In addition, the effects of the sanctions are investigated on a regular basis by a Panel of Experts, which is mandated to report on adverse effects on the population and to provide recommendations to reduce these effects. ${ }^{47}$ The most relevant question therefore seems to be whether the measures themselves, including the humanitarian exemptions, can be considered proportional in the first place. This requires a re-assessment of this practice in light of the definition of proportionality.

This article set out to assess proportionality within the context of the Security Council's practice, focusing specifically on proportionality in the design of sanctions regimes adopted pursuant to Article 41 of the UN Charter. It defined proportionality in this context as the need to ensure that "the coercive consequences of the application of sanctions, which may be felt by civilian populations, third states or individuals, remain in proportion to the harm caused by the target against which sanctions are imposed and are consistent with the objectives for which sanctions were employed."48 It further argued that it follows from this definition that proportionality plays a role in the Security Council's targeting decisions on the one hand and in the determination of whose interests are affected by the sanctions on the other.

The Security Council's principal tools to ensure that its measures are proportional are smart sanctions and humanitarian exemptions. The Council's

46 See e.g., Report of the Panel of Experts established pursuant to resolution 1874 (2009), UN Doc. S/2019/691, 31 July 2019, para. 83 .

47 See UN Security Council Resolution 1874 (2009), para. 26.

48 Farrall, supra note 3, p. 42. 
use of these tools was assessed within the context of measures imposed to curb the illegal exploitation of natural resources financing armed conflicts on the one hand and to counter nuclear proliferation on the other. Notwithstanding the fact that smart sanctions were used in both contexts, an important difference emerges from the analysis of the relevant sanctions regimes. This difference relates to the possibilities to shield third actors from the injurious effects of the Council's sanctions. As the sanctions adopted to counter the illegal exploitation of natural resources target armed groups, they can therefore benefit from State institutions by introducing mechanisms to mitigate the effects of the sanctions on the livelihood of the population. The most important mechanisms include certificate-of-origin regimes and due diligence for supply chains. Such possibilities do not exist when it is the State apparatus itself that is the target of sanctions. The analysis of the DPRK sanctions regime demonstrates that the imposition of sanctions, albeit smart, may nevertheless be extremely detrimental to the population. The inclusion of humanitarian exemptions is essential to mitigate these effects, but even these may not be sufficient.

This raises fundamental questions with respect to the interpretation and application of proportionality. This article argued that proportionality requires that there is a proper balance between the injury caused by the measures taken and the gravity of the situation that these aim to address. With respect to North Korea, the threat to the peace ensues from the proliferation of nuclear weapons. This is in itself a grave threat because of the highly destructive nature of these weapons. Based on this assessment, one may therefore conclude that it is warranted to adopt robust measures to counter this threat, even if these cause great injury to third parties. However, most of the measures that have been adopted to counter this threat are indirect, as they focus on cutting off financing for these programmes. Whether it is proportional to adopt extremely injurious measures that only indirectly contribute to countering a threat to the peace is highly questionable.

Similar questions can be raised with respect to the Council's approach with respect to natural resources and, more specifically, with respect to its targeting decisions. This relates to the first step in sanctions design, namely the decision on how to delineate the group of individuals and entities that are subject to the sanctions. Is it proportional to target the whole supply chain or should the Council instead focus on actors that directly engage with armed groups? Or should one argue that the Council has already limited the number of targets by focusing primarily on the private sector? Arguably, the Council's approach with respect to the illegal exploitation of natural resources is proportional, as it targets those who are directly implicated in activities that contribute to a 
threat to the peace and it carefully distinguishes between the responsibilities of actors based on their position in the supply chain. In this sense, the Council's practice has introduced a second layer of proportionality, namely within the group of targets.

In conclusion, both case studies clearly demonstrate the challenges in applying proportionality in sanctions practice. They demonstrate that weighing the various interests involved in a way that ensures a proper balance between them is not a simple exercise, considering that it is difficult to compare the relative weight of the interests involved. Yet, they also demonstrate the potential for innovations and the Council's willingness to engage with these questions. This is essential, as ensuring proportionality is a continuous responsibility, which requires the Security Council's enduring commitment with respect to monitoring its standards of protection and its willingness to revise its measures to uphold these standards. 